\title{
Views of University Teachers after Implementing the Proposals of the European Higher Education Area (EHEA)
}

\author{
Montserrat Alguacil, Maria-Carme Boqué, Mercè Pañellas \\ URL-FPCEE Blanquerna
}

\begin{abstract}
Taking into account studies that indicate the relationship between teacher satisfaction and student performance, this research analyzes the views of university teachers after implementing the proposals of the European Higher Education Area (EHEA) for an academic year. We also reflect about new methodologies and teaching and learning scenarios in order to clarify the changes university teachers have to make in order to work according the EHEA. The research was conducted at the University Ramon Llull in Barcelona with an intentional sample of thirty teachers who where selected according to two criteria: having at least five years of experience as teachers in the same degree, in this case the Teachers Training Degree, and their familiarity with academic subjects that involve methodological and didactic reflections. For data collection, two instruments were used: a questionnaire designed for this research and validated by experts, and a focus group. The analysis of results established a high degree of satisfaction in most categories, showing the assessment category the lowest score.
\end{abstract}

\section{Introduction}

The fast changes occurring in our society require a thorough reflection on higher education. Conclusions from the Tuning project [14] emphasize that, to cope with the increasing demands of a lifelong learning oriented society, the challenge of higher education is to be flexible to meet such requirements. Teaching, then, should aim at training people capable of managing knowledge, updating it, selecting the most appropriate data according to each context, as well as understanding what they learned so that it can adapt to new and changing situations.

Living in today's society of information and knowledge [7] involves the development of new skills by all citizens and, consequently, an active attitude towards continuous learning throughout life. Hence, the mission of higher education institutions becomes central when understanding and projecting in the syllabi the competence profile needed in each context.
Nowadays, universities have the responsibility of integrating new ways of building knowledge, adapting the teaching quality according to current parameters and ensuring the employability of future graduates.

Principles of compatibility, comparability and competitiveness of higher education across Europe have been formulated in order to promote the students and graduates mobility. But in turn, they affect the design and development of curricula and the information they provide, which has to be reliable and objective, for effective training in the different degrees. Therefore, curricula should be defined in terms of competences and learning outcomes [14].

Other studies show what skills are valued in this new environment [12], highlighting that the professional context considers university training essential, however it also identifies several deficiencies in the graduates ability to put their knowledge into practice, in communicating what they know, in managing knowledge in specific contexts or in solving problems from a holistic perspective, among others. It is possible to conclude that graduates better demonstrate their competence in those areas where more development opportunities have been provided, such as theoretical knowledge [19].

According to the CYD study [12], results of the employers' survey show that companies select their employees in terms of their potential for knowledge. As for specific knowledge, having a university degree is highly valued, but at the same time other skills and abilities considered important by respondents, were identified as gaps in graduates' training: teamwork, responsibility, initiative, adaptability and flexibility, or organizational skills and planning. This study suggests possible measures to be adopted and identifies as crucial the introduction of new teaching methods that facilitate to students the progressive accomplishment of skills that assist their subsequent incorporation into working life (organization, teamwork, oral presentations, report writing, development of research and reflection, project design, case studies, participation in seminars and debates, organizing events ...) and besides, introducing entrepreneurship aspects in the university education framework, through factors such as creativity and innovation. 
The same study [12] constitutes an observatory to identify the evolution of the relationship between the university and the economic and labour environment: to assess aspects of the Spanish university system related to the economy and society. Furthermore, we must consider the relevance of university education in the workplace, since data show that since 1964 the Spanish population with higher education has experienced a CAGR of $8.4 \%$. Data from 2009 show an inflection regarding aspects valued upward for three consecutive years, expressing a general decline in the contribution of universities to development, a drop in the level of relative improvement trends expressing Annual evolution of this contribution and a higher importance to matters related to the employability of graduates and the conditions that facilitate their employment. It's important to pay special attention to the over-qualification of employees (in 2008, almost $3 \%$ of people contracted with a university degree, performed tasks that did not require a high level of training).

Referring to knowledge - socio-cultural factors Pozo and Pérez Echeverría [19] draw attention to how its evolution is directly linked to the technical development of the context. The production, dissemination and sharing of knowledge are related to the knowledge technology prevailing in each society, not only as a means but simultaneously configuring and determining its management and scope. The information society has evolved into a knowledge society, so that information is bound to turn into knowledge [7].

The current practice of science, as critical and analytical activity, would not have been possible without the availability of new forms of reading which generate new learning cultures [19]. New generations are born within the ICT paradigm, referred to as digital natives versus digital immigrants; these generations change the printed book for the screens.

Moreover, the environment provides an excess of information, resulting in intellectual uncertainty. The trend is to move towards more opened evidence and to build situation models addressed to solve problems that are not concluding, which implies learning to live with diversity of perspectives and with plurality of theories to finally reach a view [17].

The epistemological factors from where knowledge is addressed also point to a new way of understanding it. Knowledge is not the pursuit of truth, but the construction of theories that model reality. The effectiveness of knowledge will be higher according to the number of problems or situations that concern or interest us that can be interpreted [19]. Or as explained by Morin [17] from the epistemological constructivism view, the role of knowledge is to build maps of the territories that are to inhabit, a constant dialogue with uncertainty.

The analysis of the environment from the psychological and educational perspective, as well as the and new way of teaching and learning conceptions, have advanced from reproductive learning oriented models towards cognitive models for strategic training, where you should take the cognitive processes (perception, attention, motivation, reasoning and so on) to learn maps from which the world is interpreted and transferred to new contexts and situations.

In this context, learning consists of learning to keep learning, that is, we are referring to training throughout life. The question here is how to discern what students should know in ten years and how will they cope with the demands asked by society and the profession [16]. Indicators from projects and studies mentioned above, as Tuning and CYD, provide references on what current needs are: training competent professionals, able to adapt and respond to changing and flexible professional demands and to respond to future needs in the management and use of complex knowledge; in short: flexible learners, efficient and autonomous, with self-learning capabilities, able to manage knowledge: to learn, spread, produce and use new knowledge in different manners [16]. Under these contextual conditions, higher education degrees have to be designed so as to harmonize with the current needs. Another change is the challenge of targeting training processes to student learning, which forces the implementation of new teaching approaches to develop learners' competences.

The Bologna Declaration of 1999 implied, among other important changes in university, an innovative methodological perspective that led to designing new curricula. The development of students' competencies, understood as skills to be promoted that incorporate academic knowledge but also professional practice, needs a review of teaching organization, resources, methodology and evaluation in order to respond positively to the opportunity offered by the new higher education scenario. In the process of competencybased training, learning and teaching strategies must be action-oriented and put participants in the core of the work situation, as Tejada [23] affirms. In this framework, the teacher satisfaction and commitment towards the new model of competence is highly relevant.

Following several studies, such as Fuentes [11] and Cano [5], that find a direct relationship between teacher satisfaction and student performance, we decided to find out the views of teachers after implementing the new curriculum for an academic year. A positive perception from teachers develops expectations that are associated with better student 
performance, so that, a greater degree of teacher satisfaction endures a higher efficiency in students.

Likewise, teachers' attitudes and behaviours, their expectations, their own assessment as a person and as a teacher, classroom management or personal way of being in the classroom are some of the aspects that influence more directly and effectively in the formation of a positive self-esteem in pupils [18].

Therefore, it is essential to consider aspects such as satisfaction and motivation in the curricula design and in college organization because they have great impact in teachers and learners, even more when facing the implementation of a new model. From this perspective, there is no doubt that teaching satisfaction is a key element for achieving effectiveness in organizations. In this sense, we agree with Fuentes [11] who indicates that management strategies that seek the quality of universities have to facilitate and increase teachers' fulfilment. Indeed, as Saenz and Lorenzo [21] point out it is very difficult to lead a human group if its members are not committed and motivated by common goals and collective purposes.

\section{Designing a new teaching model}

The methodological and organizational rethinking of the concept of learning, has led us to formulate a proposal for a university teaching model in the Teachers' training degrees. This model is rooted in the development of cognitive, social and professional skills, in which the leading role of the student and the guidance nature of the teacher's task concur in a constructivist view of teaching.

Here, learning takes place through a modular system were teaching resources are aimed at developing skills from various activities that include aspects of one or more disciplines [15].

Each module is given in a semester or along the academic year through different learning spaces. In these spaces diverse areas of knowledge are integrated in a trans-disciplinary way, thus, students can realize and understand the strategic links between these disciplines, as indicated by Chamorro [8], as well as apply their knowledge to new situations by establishing relationships between these conditions and previously known ones.

The work required to the student is progressive in regards to strategy development, conceptual understanding and reflection on his or her own learning processes. The starting point is always an open approach to a problematic situation selected according to specific objectives, so that during the learning process the student will acquire the necessary skills to resolve the situation. It is important to state that these modules require continuous evaluation and feedback as well as meta-cognitive reflection on the process by both the student and the teacher.

\subsection{Teaching and learning spaces and scenarios}

As indicated by Delgado [10], in this model the student becomes the centre of the learning process and the total volume of work, whose rating unit is the ECTS, is completed through various teaching spaces. However, the complex academic adaptation required by the new teaching model also needs an adaptation and reorganization of physical spaces inside the university and in connection with the city too. Precisely, this is the model that will be presented for evaluation to the teachers who implemented it during the first semester of the first course of the Bologna Plan execution. The following paragraphs describe each of the elements of the different educational spaces and scenarios.

The university should be an architectural, environmental and sustainable paradigm. Moreover, being its mission to train the whole person, the physical spaces should generate wellbeing, transmit values and motivate towards learning. For these physical spaces we must think about:

- The building, which should be considered from the perspective of an open working place, where flexible groups of different ratio are allowed. This infers the abandonment of the idea of fixed class spaces and unique groups with a single teacher. Consequently, it involves adapting the classrooms to multidisciplinary teaching and working spaces.

- The campus, which should stir up feelings of belonging in students and encourage learning in a harmonious environment.

- The merger with the city environment, so as to share resources and infrastructures and support research in order to contrast theory and practice.

Teaching and learning scenarios have to integrate skills, academic and idiosyncratic knowledge, emotions and values to place students in the world as constructive, concerned and reflective citizens. They have to become a community where people enrich each other in the way they act, think and communicate, through one's actions and those of others. This means, to build a critical community formed by people engaged in a life devoted to understanding the world. So it is important to create a social context in the classroom as a pattern of interaction processes, a challenging structure that involves the spheres of thinking and communicating, always as a reflexive action [13]. Of course, the model of teaching and learning that underlies the university teaching proposal 
presented here requires prior planning and organization of work by teachers.

Below, we display a scheme that specifies the new teaching scenarios, the time spent on each one of them and a generalized design of studies - that can be implemented in different areas of knowledge - which incorporates the objectives, phases and assessment. As said before, this model requires a number of different educational scenarios that interrelate and allow student active participation. These scenarios are large group sessions; work sessions in small groups; seminars; internships in schools; virtual campus; interuniversity activities and synergies; and individual workspace. The interaction and integration of the different areas is an important element in our proposal.

The large-group is a space where the classes are taught through expository talks. It is intended as a forum, where teachers place the items to work about, explain the relevant concepts and periodically summarize the work already done, indicating new contents and developing new strategies to advance. The activities are based on previous students' knowledge and foster processes of discovery and significance. All students are participants in their learning process designed around open problems that generate a hermeneutic nature of practices, which opens up new needs and questions that allow them to search and build new answers.

The small-group work has two objectives: one aimed at learning and another that deals with openness to others, communication, exchange, discussion and so on. It requires collaboration among equals and between teachers and students. Group members support each other and help each other understand the theories and make the effort to develop a project or solving a complex problem. The work identified and initiated in the large-group continues cooperatively into smaller groups, requiring different strategies to integrate the contributions of all members. This is an intra-group variety of study regularly reviewed by teachers affecting the module (continuous assessment) who guide the group academically, help them to overcome the difficulties that may arise in the learning process, facilitate and encourage reflection and discussion to generate new strategies and ways of research and provide continuity and quality to the work that is being done.

Seminar, in the etymological sense, means "seed and soil" which suggests a kind of space where ideas germinate and achievements and knowledge belong to the group. Therefore, the seminar allows a process of collective construction of knowledge achieved from the interaction between the members of a heterogeneous group, working in equal level with a tutor who promotes and facilitates this process [2]. As a result, the seminar is an exchange of information and practical experience that enhances in-depth reflection, so we can consider it as a space for socio-cognitive conflict generation. It is also intended that the seminar encourages responsibility and commitment to carry out a good group work. In a similar way, students deepen in their professional knowledge, linking theory and practice through reflection about their internships in schools.

Each seminar is supervised by one of the professors who teach the subjects that integrate the module, but it can affect, at special moments, other teachers inside or outside the university, depending on the area of study and reflection. Summarizing, the ultimate goal of this gathering in small groups is to promote the student's formation in touch with reality and to help them build their professional profile. Consequently, there cannot be any seminar materials selected in advance although the seminar work is part of the module work. The functions of the seminar can be summarized as:

- student guidance and assessment;

- experiencing a working environment of intellectual stimulation;

- contributing to student intellectual and professional experience though the seminar tutor advise and the other teachers that affect the matters covered by the module;

- promoting the capacity of interdisciplinary synthesis and the applicability and transferability of knowledge to professional practice;

- encouraging the acquisition of strategies and techniques addressed to autonomous learning based on personal and group interests;

- building skills for dialogue, contrasting opinions, argumentation and rhetoric speech;

- and developing capacities related to personal improvement and self-assessment of the learning process.

As mentioned, the seminar requires a joint effort between students and teachers and it is the ideal place to have an impact on three areas:

- the intellectual and social level, in order to academically develop from situations where socio-cognitive conflict is present, becoming aware of one's cognitive processes and exchanging different views within an inclusive and constructive communication frame.

- the professional performance, with the aim of exchanging experiences through internships in professional contexts, approaching different models of schools or learning styles and developing research tools, using and evaluating them.

- the humanistic and cultural field, with the aim of undertaking personal improvement for themselves and others sake, as well as 
becoming able to analyze the social and cultural reality of the immediate environment and the world.

Internships in schools or similar educative settings also include special activities carried out outside the university and in contact with the context. Its objective consists of providing authentic experiences to students. Our special activities week (SAW) reflects the desire of furnishing first-year students - who have not started internships in schools - opportunities for professional debate. For this reason, we organize a series of activities that allow the future teacher to approach their professional role.

Among the different proposals we include: short stages in a school (under the supervision of the university tutor and a 3rd. year student placed in the school), visiting schools noted for its defining characteristics as particularly relevant centres, lectures, round tables, workshops and participation in cultural events such as concerts, theatre, cinema, art exhibits and so on. Internships in schools start the second academic year and are an essential part of the Teachers' training studies because of the importance of praxis in the initial teachers' training.

Thus, the stages are carried out in all the following courses and every year the amount of credits devoted to it rises. This period of professional practice encourages the awareness about the diversity and plurality of educative models in different areas. Also, it helps students to realize and learn the importance of adapting their performance to the problems aroused in each context. This link between both the academic reality and the current reality of the profession allows a methodological and continuous intervention, altogether with the rest of activities developed through the different scenarios that integrate the modules.

Therefore, internships also seek to link the theoretical foundations, approached mostly in the large-group and small-group scenarios, with the reflective practice and the student's critical thinking attached to real contexts. In this sense, a module also requires an educational intervention in the school classroom. Such intervention has to be prepared and contrasted in the light of the knowledge acquired in the different spaces of individual and collective work. In this way, students not only observe and reproduce patterns, but also contribute to the improvement of teaching. Internship mentoring is performed by the seminar tutor, who works closely with the school tutor, in terms of orientation as well as of monitoring and evaluation. At the beginning of the course, both tutors meet to discuss how is to be reflected in the school setting the work that students will have to develop, which means that this educational intervention is not an isolated element only related to the task that children are doing at a particular moment, but that is part of a project already initiated by the school teacher and that has continuity along the term or the year. Therefore, common criteria between university and schools are adopted in order to boost a fruitful collaborative work.

Virtual platforms, on-line resources and digital contents support classroom training, since the integration of different typologies of teaching and learning in diverse environments is a key to promote change and quality. Information and communication technologies help students to search for information, edit documents, use shared folders aimed at cooperative work, participate in forums, communicate by e-mail, follow lectures and events, contact people, translate articles and much more. So, our virtual campus plays a significant role in the university life.

Apart from the areas outlined above, interuniversity activities and synergies are important elements to consider because of the opportunities that it brings to enrich the learning of all students, as well as for the opening to new perspectives that a single campus would not provide. We refer to joint work with groups from other universities, in part thanks to the virtual campus that opens the door to these new possibilities and. Similarly, projects and contracts between universities allow students exchange and even give them the opportunity to follow their studies through joint degrees.

Finally, individual work has to initiate and complete the group work, because we consider most important that students develop their own learning strategies, get motivated and prepared before approaching problematic situations to be solved in class, accept their responsibility towards collective development, and reflect on their own learning process. Furthermore, it should be noted that any teaching and learning model should preserve the uniqueness and individuality of the instructional process.

\section{Objectives and purposes}

The main objective of this research is to gather the teacher's opinion after the first year of the Bologna Plan implementation in order to realize how they appraise the changes introduced in their professional activity.

The results of this research will provide valuable information to introduce the necessary changes or adopt those aspects that foster teachers' satisfaction and have a positive repercussion in students' academic performance.

And the global purpose of the study is to collect information from all the university agents involved in the development of the EHEA directions. So that, we will proceed sequentially: first year we focus on teachers, second on students, and third on staff. 
Once triangulated, the results will remark the positive and negative aspects of the changes introduced and the common and opposed perceptions among the three collectives studied.

\section{Method}

The study combines quantitative and qualitative methods to analyze data collected through a questionnaire - designed for this research and validated by experts - and a focus group.

\subsection{Sample}

The subjects involved in the research are teachers of the first course of the Teachers Training Degree that in the Spanish catalogue of university degrees has been newly denominated as "Primary Education Degree". All of them have implemented the new curriculum in the Ramon Llull University, specifically in the Blanquerna Faculty of Psychology and Educational and Sports Sciences, settled in Barcelona (Spain). To select the sample we took into account two criteria:

a) To teach a subject that would intrinsically include a reflection on the teaching and learning process.

b) To have at least five year-experience in the course that is being assessed in order to be able to sense the innovations due to the new curriculum.

The final sample was composed by 30 university teachers of first-year undergraduate primary school teachers. These teachers had between 30 and 5 yearexperience as university professors in teacher education, which ensured the participants sensitiveness to discuss and evaluate educational innovations.

\subsection{Instruments}

For this part of the study we used a questionnaire designed by the authors of this research and validated by experts.

The purpose of the questionnaire was to collect indicators of the degree of university teachers' satisfaction about the first year of implementing a new curriculum. The questionnaire was based on similar instruments applied by Aldridge and Rowley [1] and Soares, Guisande, Diniz and Almeida [22].

We have previously identified the most significant categories to specify the degree of satisfaction of teachers and students:

- Work organization

- Teachers coordination

- Perception of student performance

- Distribution of teaching spaces

- Development of extra-academic activities
- Task of the management team

- Evaluation process of students

- Development and implementation of the teaching plan

- Strengths and weaknesses

Finally, in this last open space, teachers are asked to write down what aspects they identify in the new model that should be enhanced to improve students' performance and which should be removed because they hinder students' progress.

The questionnaire gives indicators of satisfaction and motivation as perceived by the person answering the survey. The instrument consists of a set of items following a brief statement. Responses are graduated in a Likert scale of six levels.

The sections are divided into subsections composed by closed-response items and open-response items. A space for free comments and suggestions is also provided.

Regarding the focus group, whose aim was to obtain information to complete the questionnaire, the categories were as follows:

- Timetable organization, schedule and distribution of space (large group, small group or seminar)

- Development of teaching plans (content, skills, teacher)

- Evaluation

\section{Results and discussion}

In Table 1 we present the results obtained from the questionnaire that teachers responded on-line. Each row contains one of the categories explored in the questionnaire and indicated above, and the lines correspond to the percentage of teachers that answered according to that degree of satisfaction in a scale with six possibilities: (0) not satisfied at all, (1) not very satisfied, (2) nearly satisfied, (3) quite satisfied, (4) very satisfied, and (5) totally satisfied.

As we can remark, the area in which teachers are less satisfied is in the students' evaluation. In general, assessment is one of the most complex teaching and learning activities as Prieto and Pozo [20] and Pérez Echevarria [19] confirm.

Teachers say that they do not agree with the assessment process neither with the results obtained since the implementation of the new curriculum, probably because evaluating competencies is very complex and, in the end, the result of their effort is expressed by a single numeric qualification. 
Table 1. Results expressed as percentage of teacher agreement with the implementation of the 1 st course of the Teachers Training Degree in the FPCEE Blanquerna, University Ramon Llull

\begin{tabular}{|c|c|c|c|c|c|c|}
\hline$\%$ & 0 & 1 & 2 & 3 & 4 & 5 \\
\hline Work organization & - & 20 & - & 30 & 40 & 10 \\
\hline $\begin{array}{l}\text { Teachers } \\
\text { coordination }\end{array}$ & 10 & 10 & 10 & 10 & 40 & 20 \\
\hline $\begin{array}{l}\text { Perception of } \\
\text { students performance }\end{array}$ & - & 10 & - & 10 & 50 & 30 \\
\hline $\begin{array}{ll}\text { Distribution } & \text { of } \\
\text { teaching spaces } & \end{array}$ & - & 30 & 20 & 20 & 20 & 10 \\
\hline $\begin{array}{l}\text { Development of extra } \\
\text { academic activities }\end{array}$ & - & - & - & 10 & 20 & 70 \\
\hline $\begin{array}{l}\text { Task of the } \\
\text { management team }\end{array}$ & - & - & 10 & - & 10 & 80 \\
\hline $\begin{array}{l}\text { Evaluation process of } \\
\text { students }\end{array}$ & 10 & 60 & 10 & 20 & - & - \\
\hline $\begin{array}{l}\text { Development and } \\
\text { implementation of the } \\
\text { teaching plan }\end{array}$ & - & 10 & 20 & 20 & 20 & 30 \\
\hline
\end{tabular}

Moreover, they do not find easy to establish clear assessment criteria with other teachers which is now essential for coherence sake. This causes uncertainty and high stress upon teachers who do not perceive a correspondence between their attempt to innovate and the way how students demonstrate their progress and competencies. Thus, Castelló [6] indicates that it is important to design complex and continuous evaluation activities, such us case studies, portfolios, conceptual maps and so on.

Related to the category "Distribution of teaching spaces", $50 \%$ of teachers are not very much satisfied while the other 50\% agree with the new scenarios. It is possible that innovative methodologies are valued by teachers but still have to be adjusted to the number of students and to the timetable.

Regarding the focus group, Table II shows the responses in categories and examples of the answers. In general, teachers welcome the organization of training activities that bring students closer to school reality and that develop teaching skills.

Matching the results of the questionnaire, the weakest point of the new curriculum focuses on the evaluation. Teachers note an increase in the number of assignments students must deliver which, in part, can be explained by the importance given to continuous assessment and teamwork. Probably, the ability of working in a more transversal and cross-curricular way would be an answer to this problem.
Table 2. Categorization of the responses of the teachers' focus group of the 1 st course of the Teachers Training Degree in the FPCEE Blanquerna, University Ramon Llull

\begin{tabular}{|l|l|l|}
\hline Answers & Categories & Typology of reason exemplified \\
\hline \multirow{5}{*}{ - We value very positively the } \\
calendar. \\
-
\end{tabular}

\section{Conclusions}

It is quite premature to take definitive conclusions about the implementation of the Bologna Plan just from the teachers' perception after one academic year in operation. However, in our context, we have clarified some interesting questions that should be 
taken into account in order to improve teachers' satisfaction and get the benefits associated to it.

In synthesis, the majority of answers point to a good teachers' satisfaction in relation to the implementation of new curriculum connected to the EHEA. But, except for the high level of satisfaction showed about the management team and the development of extra academic activities, both elements newly introduced, there is evidence that the current process of implementation of the Bologna Plan has to be improved in our university, progressing from the quite satisfied position towards the very and totally satisfied punctuations.

In this sense, the teaching spaces will have to be better organised according to the length of groups and to the teachers' schedule.

The perceived difficulty in assessing students' performance could have a negative influence in their progress and results, as Cabrera and Galán [3] indicate. In another study, Cabrera, Bethencourt, González and Alvarez [4] say that low marks have a negative effect in first year students who could easily be discouraged and quit the university. Therefore, we agree with De Miguel [9] who affirms that it is crucial to establish support and formative mechanisms addressed to help teachers to develop useful and satisfactory assessment methodologies.

\section{References}

[1] Aldridge, S. and Rowley, J. (1998) 'Measuring customer satisfaction in higher education', Quality Assurance in Education, 6 (4), pp. 197-204.

[2] Blanquerna Facultat de Psicologia i Ciències de l'Educació (2000). Document d'identitat dels estudis de Magisteri. Barcelona, Fundació Blanquerna.

[3] Cabrera Guillén, P. and Galán Delgado, E. (2002) 'Factores contextuales y rendimiento académico', Revista Electrónica Interuniversitaria de Formación del Profesorado, 5 (3).

[4] Cabrera, L. Bethencourt, J.T., González, M. and Álvarez, P. (2006) 'Un estudio transversal retrospectivo sobre prolongación y abandono de estudios universitarios', RELIEVE, 12(1); http://www.uv.es/ RELIEVE/v12n1/ RELIEVEv12n1_1.htm (14 February 2011).

[5] Cano, E. (2007) Cómo mejorar las competencias de los docentes. Guía para la autoevaluación y el desarrollo de las competencias del profesorado, Graó, Barcelona.

[6] Castelló, M. (2009) L'avaluació de les competències a la FPCEE Blanquerna, Doccument not published, FPCEE Blanquerna - Universitat Ramon Llull, Barcelona.

[7] Castells, M. (2000) La era de la información, Alianza, Madrid.
[8] Chamorro, C. (Coord.) (2003) Didáctica de las matemáticas, Madrid, Pearson Prentice Hall.

[9] De Miguel Díaz, M. (Dir.) (2006) Metodologías de enseñanza y aprendizaje para el desarrollo de competencias. Orientaciones para el profesorado universitario ante el espacio europeo de educación superior. Alianza Editorial, Madrid.

[10] Delgado, A.Ma . (Coord.) (2005) Competencias y diseño de la evaluación continua y final en el espacio europeo de educación superior. Madrid: Dirección General de Universidades; http://wwwn.mec.es/univ/ proyectos2005/ EA2005-0054.pdf (12 December 2012).

[11] Fuentes, J. C. (2006) Incidencia de la satisfacción laboral docente y el ambiente del aula en el rendimiento académico de alumnos universitarios; http://fondosdigitales.us.es/tesis/ tesis/474/incidencia-de-la-satisfaccion-laboral-docente-y-elambiente-de-aula-en-el-rendimiento-academico-de-losestudiantes-universitarios/ (12 March 2012).

[12] Fundación CYD (2008) La universidad y la empresa española; http://www.fundacioncyd.org/wps/portal/ (10 March 2013).

[13] Gallego, C. (2008) 'Alfabetització matemática i comunitats escolars', Temps d'Educació, 34, pp. 29-66.

[14] González, J. and Wagenaar, R. (2003), Tuning Educational Structures in Europe. Universidad de Groningen y Universidad de Deusto, Bilbao.

[15] Hermansen, A., Olguín, N., and Rozas, J.L. (2004) 'Módulos de aprendizaje: Una propuesta didàctica', Extramuros, 3, 11-22.

[16] Monereo, C. and Pozo, J. L. (2003) La universidad ante la nueva cultura educativa. Enseñar y aprender para la autonomía, Sínesis, Madrid.

[17] Morin, E. (1999), Tener la cabeza bien amueblada, Seix Barral, Barcelona.

[18] Ontoria, A., Gómez, J.P.R. and Molina, A. (1999) Potenciar la capacidad de aprender y pensar, Narcea, Madrid.

[19 ] Pozo, J.L. and Pérez Echevarria, M.P. (2009) Psicología del aprendizaje universitario: la formulación de competencias, Morata, Madrid.

[20] Prieto, L. (Coord.) (2008) La enseñanza universitaria centrada en el aprendizaje, Octaedro/ICE UB, Barcelona.

[21] Sáenz, O. and Lorenzo, M. (Coords) (1993) La satisfacción del profesorado universitario, Universidad de Granada, Granada.

[22] Soares, A. P., Guisande, M.A., Diniz, A.M. and Almeida, L.S. (2006) 'Construcción y validación de un modelo multidimensional de ajuste de los jóvenes al contexto universitario', Psicothema, 18, (2), pp. 249-255. 
Literacy Information and Computer Education Journal (LICEJ), Volume 4, Issue 3, September 2013

[23] Tejada, J. (2007) 'Estrategias formativas en contextos no formales orientadas al desarrollo socioprofesional', Revista Iberoamericana de Educación, 43 (6), pp. 1-12. 